Revue bibliographique pour le domaine irano-aryen

\title{
Emidio Vergani, Sabino Chialà (a cura di). La grande stagione della mistica siro-orientale (VI- VIII secolo)
}

\section{Florence Jullien}

\section{(2) OpenEdition}

1 Journals

\section{Édition électronique}

URL : http://journals.openedition.org/abstractairanica/40897

DOI : 10.4000/abstractairanica.40897

ISSN : 1961-960X

Éditeur :

CNRS (UMR 7528 Mondes iraniens et indiens), Éditions de l'IFRI

\section{Édition imprimée}

Date de publication : 1 décembre 2013

ISSN : 0240-8910

\section{Référence électronique}

Florence Jullien, «Emidio Vergani, Sabino Chialà (a cura di). La grande stagione della mistica siroorientale (VI-VIII secolo) », Abstracta Iranica [En ligne], Volume 32-33 | 2013, document 351, mis en ligne le 01 juillet 2016, consulté le 05 octobre 2020. URL : http://journals.openedition.org/ abstractairanica/40897 ; DOI : https://doi.org/10.4000/abstractairanica.40897

Ce document a été généré automatiquement le 5 octobre 2020.

Tous droits réservés 


\section{Emidio Vergani, Sabino Chialà (a cura di). La grande stagione della mistica siro-orientale (VI-VIII secolo)}

Florence Jullien

\section{RÉFÉRENCE}

Emidio Vergani, Sabino Chialà (a cura di). La grande stagione della mistica siro-orientale (VI-VIII secolo). Milan, Centro Ambrosiano, 2010, 165 p.

1 Actes de la $5^{\mathrm{e}}$ "rencontre sur l'Orient chrétien de tradition syriaque » de la Bibliothèque ambrosienne de Milan, ce travail sur la mystique syro-orientale aux $\mathrm{VI}^{\mathrm{e}_{-}}$ VIII siècles fait un état de la question en deux volets : d'abord le contexte historique et christologique dans lequel s'est épanoui ce courant; puis une prosopographie des principales figures mystiques parmi lesquelles Dadisho' de la province ecclésiastique du Beth-Qatrayē (rattachée sur le plan juridictionnel à celle du Fārs) et Isaac de Ninive. On relèvera des contributions sur le contexte historique et ecclésial des $\mathrm{VI}^{\mathrm{e}}$ et $\mathrm{VII}^{\mathrm{e}}$ siècle, période-charnière pour l'Église de Perse confrontée à des défections en nombre face à l'avancée des nouveaux maîtres du sol, mais aussi paradoxalement dynamique dans les espaces mésopotamien et iranien. 


\section{AUTEURS}

\section{FLORENCE JULLIEN}

EPHE, Paris 